\title{
The Economic Value of Public Goods
}

\author{
Thaddeus Neil Cummins \\ Economic GPS, Denver, CO, USA \\ Email: Thadncs@gmail.com
}

Received 17 August 2014; revised 22 August 2014; accepted 16 September 2014

Copyright (C) 2014 by author and Scientific Research Publishing Inc.

This work is licensed under the Creative Commons Attribution International License (CC BY).

http://creativecommons.org/licenses/by/4.0/

c) (i) Open Access

\begin{abstract}
This paper explores US entrepreneurial history and public budgets from President Eisenhower's election in 1952 until the beginning of the Obama administration 2008. A mix of market forces, structural changes and a tendency toward unfettered capitalism [1] challenge diagnosis. This analysis examines these complexities with 216 business quarters of economic history. It also provides a mathematical model to characterize in broad strokes positive governance modeling for business. This work is important as economic growth ensures a nation's ability to protect its citizens.
\end{abstract}

Keywords

Public Goods, Entrepreneurial History, Governance Modeling

\section{Introduction}

Public goods are rarely monetized as they are difficult to trade in the markets. This has led to the belief that public goods like national defense, infrastructure and human development programs lack value in economic decision-making. In addition, economic thinkers like Milton Friedman have successfully argued that free enterprise and floating currencies will stabilize global and domestic markets [2]. Unfortunately, the rise of bank failures, bubble markets and prolonged recessions over the past three decades has undermined this long held belief.

By comparing public inputs and economic outputs, a quasi-experimental design offers useful information for public and private professionals. Based on two equally sized US economic eras (N1 = 108 and N2 = 108) over a fifty-six year period, the data show a monetized outcome preference for the Eisenhower through Carter governance models. By comparing different economic outcomes under different models of governance over decades the quasi-experimental design provides a bird's eye view of recent US entrepreneurial history.

This work is significant for local, national and global economic decision-making. Economic decision makers could benefit from understanding the links between public goods, market stability, labor participation and business risk summarized by economist Thomas Piketty. In mathematical language, Piketty's dynamic reads as $\boldsymbol{r}$ (return on capital) $>\boldsymbol{g}$ (economic growth) $=>$ increased (risk) [3]. 
With the luxury of hindsight and math, adequate investments in public goods appear to decrease (risk) by growing the economy, stabilizing markets and increasing labor participation. Economies like most long term projects require sustaining capital to protect future returns. Without adequate sustaining capital, projects fail at greater rates than those with adequate sustaining capital. To this end a fluid dynamics model from physics helps measure these economic growth coefficients toward positive governance modeling for business.

\section{Quasi-Experimental Designs}

Quasi-experimental designs are useful for exploring plausible correlations between inputs and outputs in complex polymorphic systems like national and global economies where control groups are not possible.

Polynomial yield curves in Chart 1 compare different economic outcomes under different models of governance over decades. Before 1980 a higher percentage of US GDP investments in public goods appears to protect markets from prolonged recessions and broaden income distribution enriching market demand for productivity gains brought by entrepreneurial activity. By comparing two 28-year economic eras with similar amounts of war and economic turmoil yet different public investment postures a balanced quasi-experimental design provides useful information about the role of public goods in entrepreneurial success.

\section{Equation and Coefficients}

To put this in mathematical language a simple fluid dynamics model is transformed from a parasitic drag equation into a multi-variable economic boost equation. From Eisenhower through Carter, economic growth (velocity) labor participation (mass) and governance (public goods) associate with increases in economic demand likely igniting the creative forces of entrepreneurial activity. Over time adequate investments in public goods (19531979) appear to protect entrepreneurs from the risk of economic and financial instabilities found in the less resourced economies (1980-2008).

\subsection{Economic Boost Equation}

The economic boost equation (3.2) shows that adequate sustaining capital boosts economic performance over time. Economic boost coefficients frame sustaining capital measures in mathematical language for economic decision-making. Public goods historically and in this model are monetized in the belief that they contribute to positive business climates. Resilient economies maintain demand for private goods and services in evolving technological and demographic dynamics over time.

\subsection{Equation}

$$
B_{e}=\frac{1}{2} p v^{2} M_{g^{*}} A
$$

\subsection{Definitions}

$$
\begin{aligned}
& B_{e}=\text { Economic boost } \\
& p=\text { Mass and density measured as \% participation in labor } \\
& v^{2}=\text { Economic velocity represented as GDP growth rate } \\
& M_{g^{*}}=\text { Governance model }=[(\%, \mathrm{Gp}),(\text { type, Gp)], }[(\%, \mathrm{Gpr}),(\mathrm{type}, \mathrm{Gpr})], \mathrm{Gp}=\text { Pub. goods, Gpr = Pri. } \text { goods } \\
& A=\text { Areas of economic references as } \lambda \text { GDP growth/GDP }
\end{aligned}
$$

\section{Optimum Public Investments}

Public goods play an important role in providing structural integrity toward healthy and educated citizens that are the least expensive to govern. The United States economic success story includes public investments best illustrated by President Eisenhower's US highway system, JFK's promotion of positive science and President Johnson's war on poverty. Without these public investments the auto industry expansion would have been limited and technologies like Trinitron and space science would have materialized in private markets more slowly if at all. 


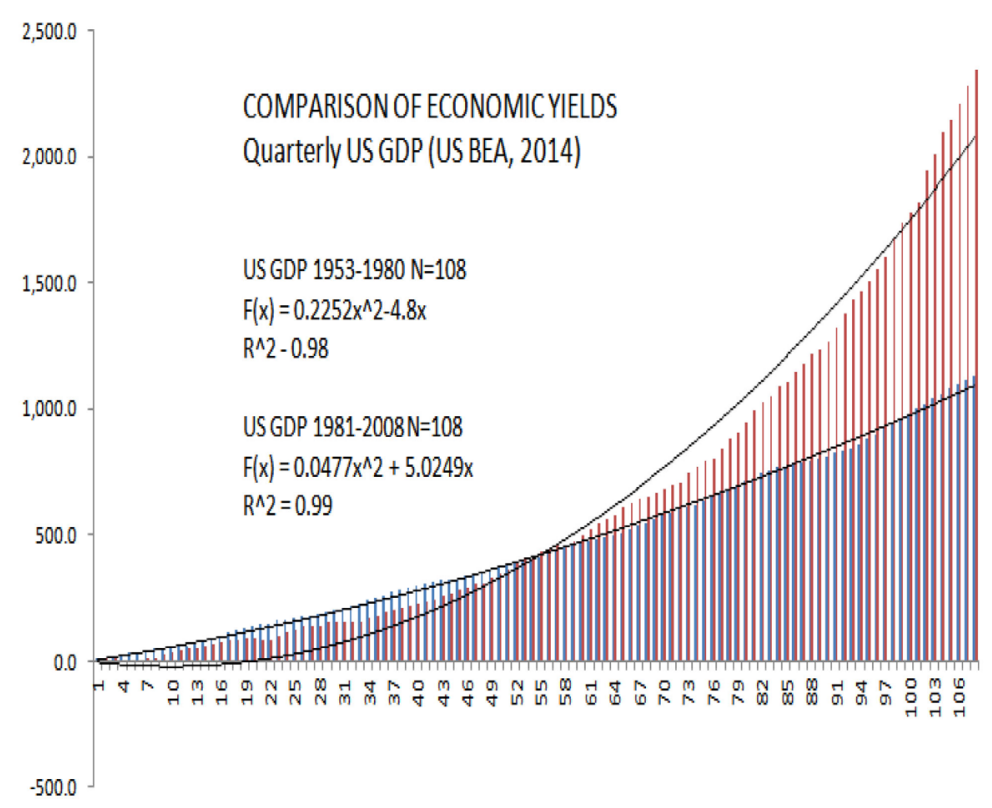

Chart 1. Comparative yield curves [4].

Without adequate public goods the business climate appears to lack demand giving way to idiosyncratic competition leading to what economist Joseph Schumpeter called creative destruction. The economic boost model seeks economic symmetries between labor, technology and capital in support of entrepreneurial productivity planning. Understanding the properties of optimum public goods investments requires ongoing analysis of positive governance modeling using Lie algebras [5] and other symmetry based mathematical representations.

The prevailing economic belief that public investments have minimal value appears to transfer costs into future generations as cost accruals, creating parasitic drag coefficients on future growth in the form of low technology transfer rates, poor use of labor and access to capital deficiencies.

\section{Changing Fortunes after 1980}

Significant improvements in labor participation rates during the US Carter administration associate with the highest US GDP growth over the 56-year study period. This supports the notion that work is a virtue required for economic and financial stability. The storyline of economic growth suggests if more citizens are working and paying taxes, each worker is a net benefit to the economy in terms of labor (mass), growth (velocity) and less public consumption drag.

An economic inflection point around 1980 pairs with a change in US economic policies driven by private capital biases away from public goods investments. The upslope and following down slope of GDP growth rates are visible in Chart 2. National security expenditures follow a steady downward slope as a percentage of US GDP 1953-2008, while physical capital expenditures also drop from 2\% to 1\% of US GDP after 1980. These decreases in public investments deliver lower economic outcomes and higher risk to private capital resulting in lower boost coefficients in the proposed positive governance model.

From these observations a healthy floor in percentage of US GDP for national security and physical sector should be considered. Specifically, Chart 2 suggests positive economic performance appears to wane when national defense expenditures fall under 5\% of GDP and physical capital investments fall below 2\%. By parsing historical budget data into greater detail, public investments appear to function differently by quantity and type before and after 1980. The relationship between public goods and economic growth as measured by high $R^{2}$ values reverses and drops 30\% after 1980. This marks the beginning of a structural shift in political economic decision-making resulting in less public investments, greater instabilities and declining economic growth rates. Moreover, GDP growth [6] declines after 1980 during a time of population and technological advancement. Similar to stagflation during the Carter administration, this should not be possible under economic theory. 


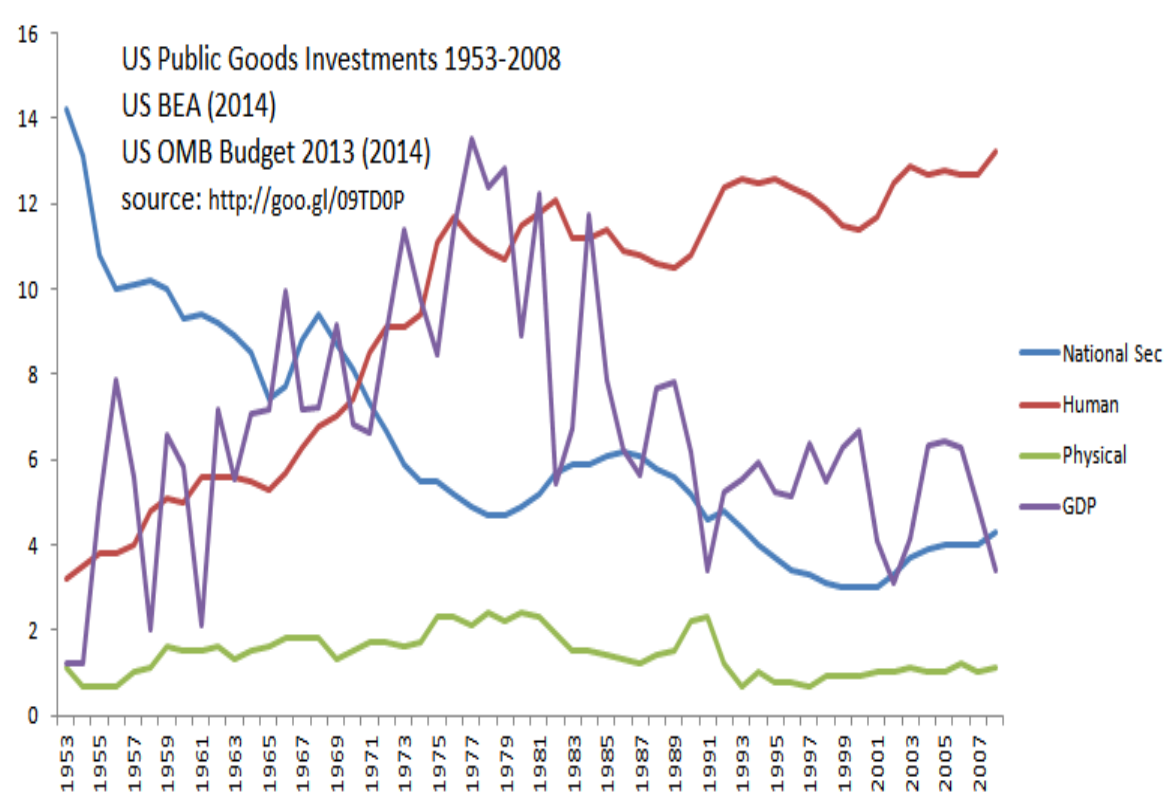

Chart 2. GDP and public goods.

Human capital investments, already explored by thinkers like Gary S. Becker [7] experienced the greatest change in type and impact after 1980. Both US GDP growth and human capital expenditures as a percentage of GDP grew in tandem 1953-1979. US public policies changed and public investments shifted away from economic boost coefficients after 1980. These altered the character and velocity of the US marketplace. A reconsideration of the value of public goods appears to be in order.

\section{References}

[1] Hibbs Jr., D.A. (1993) Solidarity or Egoism. Aarhus University Press, Denmark.

[2] Volcker, P. (2008) Changing Fortunes. Random House, New York.

[3] Piketty, T. (2014) Capital in the 21st Century. Harvard Press, USA.

[4] US OMB Historical Tables, Budget of the US Government (2013) Fiscal Year 2013, USA.

[5] Jorgensen, P. (2008) Operators \& Representation Theory. Dover, New York.

[6] US BEA (2013) US Real GDP by Year, USA.

[7] Becker, G.S. (1992) The Economic Way of Looking at Life. Nobel Lecture, Chicago. 
Scientific Research Publishing (SCIRP) is one of the largest Open Access journal publishers. It is currently publishing more than 200 open access, online, peer-reviewed journals covering a wide range of academic disciplines. SCIRP serves the worldwide academic communities and contributes to the progress and application of science with its publication.

Other selected journals from SCIRP are listed as below. Submit your manuscript to us via either submit@scirp.org or Online Submission Portal.
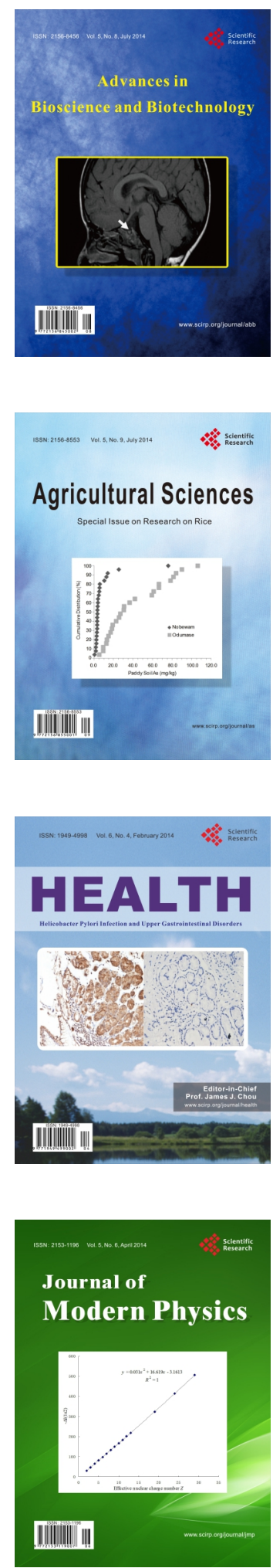
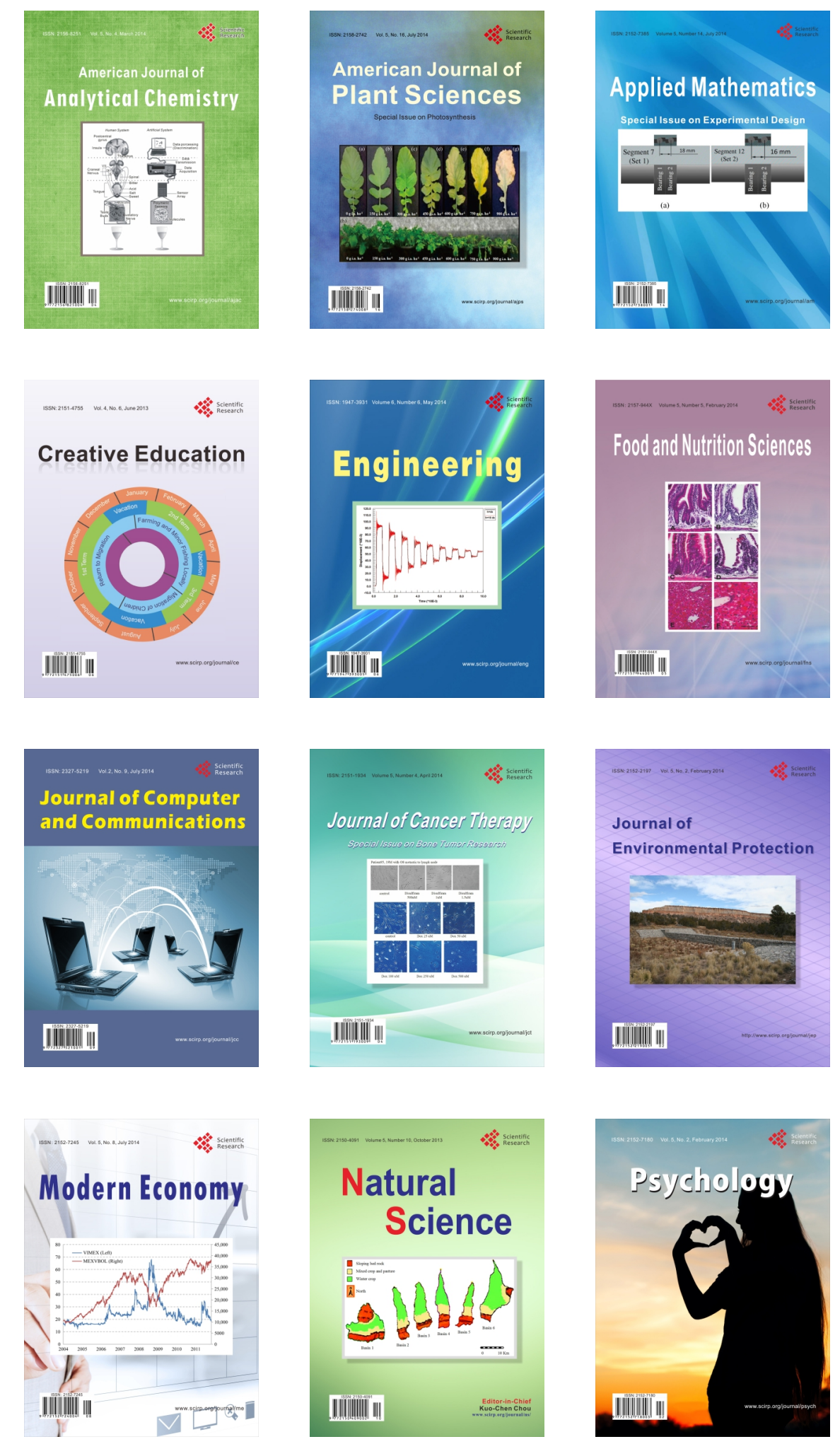